\title{
DANUTA URBANIAK-ZAJAC
}

\author{
UNIWERSYTET ŁÓDZKI
}

http://dx.doi.org/10.18778/8142-715-9.06

\section{Od uniwersalności do partykularności metody badawczej}

\section{Uwagi wstępne}

Źródłem inspiracji dla niniejszego szkicu jest tekst Mieczysława Malewskiego (2017) pt. Badania jakościowe w metodologicznej pułapce scjentyzmu. Autor przeciwstawia w nim metodologię normatywną - której kwintesencją jest "metoda przekształcona w dogmat” (s. 131) - zbliżającej się postmetodologicznej fazie uprawiania nauk społecznych (s. 135), w której to metoda ma tracić na znaczeniu na rzecz potencjału tkwiącego $\mathrm{w}$ badaczkach i badaczach. Autor postuluje ,[u]znanie praw badaczy do samodzielnego konstruowania jakościowych projektów badawczych" (s. 134). Podpisuję się pod tym postulatem, ale nie łączę go z odrzuceniem znaczenia metody badawczej, ponieważ inaczej odwracalibyśmy starą opozycję: w miejsce metody bez badacza pojawiłby się badacz bez metody. Z mojej perspektywy zmiana dokonująca się w metodologii badań empirycznych w naukach społecznych, w tym w pedagogice, wyraża się we wzrastaniu partykularności metod badawczych, co oczywiście ma konsekwencje dla warunków ich stosowania. Ów partykularyzm wynika z pozbawienia metody naukowej i adekwatnych do niej metod badawczych autonomii i neutralności.

Dokonująca się zmiana stanowi wyzwanie dla krytyki metodologicznej. Tak długo jak wierzono w jedność (w znaczeniu uniwersalności) metody, prowadzenie krytyki metodologicznej nie nastręczało większych problemów: 
polegało na określaniu „zgodności praktyk badawczych ze zbiorem uznanych reguł metodologicznych" (Malewski, 2017, s. 131). W sytuacji wielości metod odwołujących się do różnych reguł oraz braku metaperspektywy każda krytyka wyrażająca się w wartościowaniu: poprawnie - niepoprawnie, musi być również partykularna. Jest prowadzona z określonego punktu widzenia i raczej wzmacnia istniejące podziały, niż sprzyja poszukiwaniu szerszego horyzontu ujmowania zagadnień. W tych okolicznościach większy sens wydaje się mieć krytyka polegająca na rekonstruowaniu realnych praktyk badawczych ${ }^{1}$, odsłanianiu warunków, w jakich przebiegały, oraz śledzeniu relacji między deklaracjami badaczek i badaczy a obiektywizującymi się w opublikowanych tekstach wynikami badań. Ma to służyć wzrostowi świadomości metodologicznej, wyrażającej się między innymi w dostrzeganiu realnych różnic między metodami oraz konsekwencji ich stosowania dla jakości poznania. Do tych warunków należy także status nadawany metodzie badawczej. W niniejszym artykule skupiam się na okolicznościach nadających jej szczególne znaczenie i okolicznościach to znaczenie ograniczających. Dla prowadzonej analizy istotne jest przypomnienie, że metoda badawcza jest uszczegółowieniem metody naukowej, konstytutywnego elementu ideału nowożytnej nauki (Amsterdamski, 1983; Nowak, 1985). Tym samym rozważania nad statusem metody badawczej muszą być prowadzone w szerszym kontekście, wykraczającym poza ramy jednej dyscypliny (w tym przypadku pedagogiki). Metoda naukowa ustanawia strukturę procesu poznania naukowego (np. Grobler, 2006; Kamiński, 1992), metoda badawcza zaś jest konkretną formą postępowania specyficzną dla etapu procesu badawczego, a także dyscypliny.

Artykuł rozpocznę od zasygnalizowania genezy szczególnej roli metody w nowożytnej nauce. Następnie zwrócę uwagę na konsekwencje przełomu antypozytywistycznego polegające na wykluczeniu nauk humanistycznych (obejmujących także dzisiejsze nauki społeczne) z poznania empirycznego. Dalej przywołam metodę jako zbiór czynności, traktowanych w ujęciu tradycyjnym jako autonomiczne, niewymagające zewnętrznego uzasadnienia. W dalszej części zasygnalizuję okoliczności, które podważyły tę autonomię, a także następstwa tej zmiany dla praktyki jakościowych badań empirycznych. W efekcie prowadzonych rozważań zastanowię się w zakończeniu nad funkcjami metody badawczej oraz specyfiką współczesnej krytyki metodologicznej w naukach społecznych, w tym w pedagogice.

1 Tak rozumianą krytykę można prowadzić w odniesieniu do działań własnych (taką próbę podejmowałam w tekście Proces badawczy jako podejmowanie decyzji - refleksja metodologiczna, w: D. Kubinowski, M. Chutorański (red.), Pedagogika jako humanistyczno-społeczna nauka stosowana: konsekwencje metodologiczne, Kraków: Oficyna Wydawnicza „Impuls” 2017) albo prowadzonych przez innych. W tym drugim przypadku warunkiem ją umożliwiającym jest przedkładanie przez autorki i autorów publikacji informacji o drodze ich postępowania badawczego, czyli o zastosowanej metodzie. 


\section{Geneza wyróżnionej pozycji metody}

Cechą nowożytnej nauki jest poznanie empiryczne. Z jednej strony wiadomo, że wiedza empiryczna jest stale rewidowana, a więc - wbrew potocznym mniemaniom - wiedza naukowa jest niepewna. Z drugiej w klasycznym ujęciu czynnikiem nadającym wartość tej ostatniej jest szczególna metoda jej pozyskiwania². Rodzi się pytanie: skąd pochodzi szczególna pozycja metody? Zdrowy rozsądek podpowiada, że wartościowa jest taka, która pozwala osiągnąć konkretny, zamierzony cel. Przykładem takiej metody jest opracowany przez Aleksandra Wolszczana sposób identyfikowania planet poza Układem Słonecznym. Kiedy upublicznił on metodę, za pomocą której odkrył pierwszą planetę, we Wszechświecie zaroiło się nagle od tych ciał niebieskich. Stosowanie metody przez innych astronomów dowiodło jej dużej skuteczności (Ulanowski, 2008). Wiemy, że tak bezpośredni związek między metodą a celem, jakiemu ona służy, w naukach społecznych (w tym w pedagogice) występuje bardzo rzadko i z reguły jest konsekwencją umowy (np. celem stosowania Kwestionariusza Gotowości Przeciwstawiania Się jest pomiar gotowości przeciwstawiania się; Pasikowski, 2016). Z prowadzonych historycznych analiz wynika, że nadanie wysokiego statusu metodzie w nauce nie było konsekwencją uzyskiwanych za jej pomocą efektów. Odwołując się do badań Marka Siemka (1989), można powiedzieć, że szczególną wartość metodzie naukowej nadała filozofia. Początkowa treść pojęć „nauka” i „naukowość” została ustalona przez filozofów przed powstaniem nowoczesnej nauki - „[...] cała klasyczna filozofia - przynajmniej już od Platońskiej episteme [...] pojmuje siebie zawsze jako »naukę«, tak jak odwrotnie, »nauka« znaczy zawsze dokładnie to, co »filozofia«" (Siemek, 1989 , s. 16). Kiedy nowożytna nauka zaczęła wyodrębniać się w Oświeceniu jako nowy, specyficzny, empiryczny fenomen, filozofowie odnieśli do niej swoje stare, filozoficzne, przednaukowe pojęcie. Zgodnie z nim „»nauka« to ni mniej ni więcej, tylko sam poznający Rozum, który ujmuje Prawdę, a więc dociera do Bytu w jego esencjonalnej, a zarazem wartościowej strukturze" (Siemek, 1989, s. 17). Filozofia, broniąc starego pojęcia przed nową rzeczywistością, sama przyjęła status nauki ogólnej, sytuującej się ponad realnymi naukami szczegółowymi. Zajmowała się tym, czemu coraz bardziej specjalizujące się dyscypliny szczegółowe nie poświęcały uwagi - budowaniem jedności nauki. Filozofią utożsamioną z nauką, której obraz sama stworzyła, był scjentyzm. Ponieważ naukę uznano za kwintesencję mądrości i prawdy, istotną kwestią stało się wyznaczenie granicy między

2 „Istotnym sprawdzianem naukowości, posiadającym przy tym ogromne walory dydaktyczne i wielostronną użyteczność, okazuje się metoda uprawiania nauki. Ona prezentuje to, co dla wszystkich typów poznania naukowego jest najbardziej wspólne (J.G. Kemeny)" (Kamiński, 1992, s. 200). 
tym, co nią jest, a co nie. Stosowne kryteria demarkacji przedłożył - wyrastający z krytyki scjentyzmu - pozytywizm, określając reguły, których należy się trzymać, aby zadawać sensowne pytania i odrzucać źle postawione (Kołakowski, 2003). Relegował on metafizykę (a więc filozofię) z zakresu dociekań naukowych i stworzył warunki do skodyfikowania uniwersalnej, wolnej od założeń, i w tym znaczeniu neutralnej, metody naukowej.

Podsumowując, szczególny status metody naukowej miał pozanaukowe uwarunkowania, był konsekwencją zabiegania filozofii o zachowanie wyróżnionej pozycji wobec instytucjonalizujących się pomału dyscyplin naukowych. Służyło temu przenoszenie jej reguł w dziedzinę nauki. Filozoficzny obraz nauki przysłaniał naukę realną, w istocie zniekształcając jej obraz. Praktyka badań empirycznych nie rościła sobie pretensji do ostatecznego poznania, nigdy nie było jej obce działanie metodą prób i błędów. A jednak przez długie dziesięciolecia badania naukowe przedstawiane były jako w pełni racjonalne przedsięwzięcie, prowadzone przez wyłącznie racjonalne podmioty zmierzające w kontrolowany sposób - za pomocą uniwersalnej metody - ku Prawdzie. Mimo że scjentyzm jako stanowisko filozoficzne został odrzucony, wiara w moc nauki pozostała, a pozytywizm dodał do niej wiarę w moc naukowej metody. Położono tym samym kamień węgielny pod ogólną metodologię nauki, tworzonej przez filozofów i logików, którzy nie prowadzili badań empirycznych, a przecież to ten rodzaj poznania był wyróżnikiem nauki nowożytnej.

\section{Znaczenie przełomu antypozytywistycznego dla nauk społecznych}

Pozytywizm prezentował naukę jako pozbawioną metafizyki, badającą wyłącznie fakty, co pozwoliło filozofii przyjąć pozycję jej zewnętrznego krytyka. Krytyką pozytywizmu była filozofia życia sytuująca się jednoznacznie obok nauki, budująca „swe własne królestwo wiedzy o »znaczącej« rzeczywistości ludzkich dążeń i działań, sensów i celów, ideałów i wartości” (Siemek, 1989, s. 27). Zdaniem Siemka filozofia chciała w ten sposób ochronić humanistykę jako swoją wyłączną domenę. W nurcie filozofii życia mieści się koncepcja Wilhelma Diltheya odróżniająca nauki humanistyczne od przyrodniczych w efekcie przypisania im odmiennych metod. Jak powszechnie wiadomo, za metodę nauk humanistycznych przyjął on rozumienie. Pisał:

\footnotetext{
Warunkiem rozumienia jest przeżycie, ono zaś staje się doświadczeniem życiowym dopiero dzięki temu, że rozumienie przekracza charakterystyczną dla przeżywania ciasnotę i subiektywizm na drodze do tego, co całościowe i ogólne. Ponadto, o ile rozumienie pojedynczej osobowości, jeśli ma być doskonałe, wymaga systematycznej wiedzy, o tyle systematyczna wiedza zależy od zrozumienia indywidualnych całostek życia (Dilthey, 1987, s. 209).
} 
Przywołana wypowiedź pokazuje, że rozumienie jest raczej celem poznania niż metodą. A jeśli już nią jest, to nie jako zbiór czynności, które można opanować i w dowolnym kontekście stosować. Metoda w ujęciu Diltheya nie ma charakteru czynnościowego, lecz przedstawia warunki, w jakich rozumienie przebiega. Konsekwencją eksponowania przez badacza kategorii przeżycia jest dzisiaj zbytnie utożsamianie rozumienia z introspekcją i empatią. Niektórzy współcześni badacze i badaczki prowadzący jakościowe badania empiryczne widzą istotę hermeneutyki we „wczuwaniu się" w przeżycia innych, a wcale nie biorą pod uwagę postulatu łączenia tego, co indywidualne, z tym, co ogólne.

Warto sobie uświadomić, że separacji filozofii życia od nauki towarzyszyło usunięcie z nauk humanistycznych, przyjmujących program filozofii życia, badań empirycznych. Dlatego np. kształtująca się w Polsce w okresie międzywojennym pedagogika społeczna, eksponująca znaczenie warunków życia dla rozwoju i kształcenia dzieci, na płaszczyźnie metodologicznej w ogóle nie odnosiła się do pedagogiki humanistycznej. Koncepcja Geistwissenschaft aż do końca lat 60. XX wieku bardzo silnie warunkowała jednak sposób uprawiania pedagogiki w Niemczech. W tym kraju nurt empiryczny (w tym eksperymentalny) tworzył jedynie wąski margines, nieakceptowany przez akademicki pedagogiczny mainstream. Dopiero postulowana w 1962 roku przez Heinricha Rotha konieczność realistycznego zwrotu w badaniach pedagogicznych (niem. realistische Wendung) zapoczątkowała, wzmocnione ruchami społecznymi 1968 roku, dyskusje nad ograniczeniami historyczno-filozoficznej perspektywy badawczej, co w efekcie znacznie zwiększyło znaczenie badań empirycznych w pedagogice naszych sąsiadów (Lehrberger, 2009).

Podnoszę kwestię pierwszego przewrotu antypozytywistycznego, by zwrócić uwagę, że nie miał on znaczenia dla zmiany ówczesnego obrazu nauki. Ograniczył tylko jej zakres do dyscyplin stosujących poznanie empiryczne, czyli posługujących się metodą naukową. Humanistyka stosująca inną metodę stała się z definicji nienauką, jej przedmiotem nie był świat empiryczny (natura), lecz wytwory ducha ludzkiego, najczęściej teksty - te uznane za wartościowe. Geistwissenschaftliche Pädagogik nie badała realnych warunków wychowania, lecz skupiała się na tym, jakie one powinny być, aby możliwe było realizowanie jego ideałów.

Powierzchowne współczesne odniesienia do przewrotu antypozytywistycznego wykorzystywane są dla uzasadniania opozycji: badania ilościowe - badania jakościowe, z tendencją do kwestionowania wartości tych pierwszych. Jest to zgodne z duchem filozofii życia, która wypowiedziom o nauce nadawała pejoratywny odcień emocjonalny, wyrażający się w takich określeniach, jak „mit nauki”, „fetysz nauki” (Siemek, 1989, s. 27). To nastawienie stanowiło rewers medalu wykutego przez scjentyzm 
i pozytywizm, przyjęło tym samym, że pomiędzy naukami przyrodniczymi i humanistycznymi istnieje nieprzekraczalna różnica, co współcześnie przenoszone jest na badania ilościowe i jakościowe.

\section{Metoda badawcza jako zespół czynności}

Ogólna metodologia nauki tworzona była i nadal jest przez filozofów - nieprowadzących badań empirycznych, mimo że ten rodzaj poznania jest wyróżnikiem nauki nowożytnej - którzy nadali sobie prawo zabiegania o jedność nauki. Sposobem na osiągnięcie tej jedności miała być jedna metoda, wynikająca z określonego pojmowania nauki. Na gruncie badań empirycznych została ona przekształcona w zespół czynności ukierunkowanych na identyfikowanie faktów i powiązań między nimi. Czynności te, traktowane jako neutralne wobec przedmiotu, w połączeniu z poprawnością ich wykonania mają prowadzić do obiektywnego poznania. Niezależnie od filozoficznych debat dotyczących warunków i specyfiki poznania naukowego wypracowano tylko dwa czynnościowe wzory metody naukowej w badaniach empirycznych: weryfikacyjny i hipotetyczno-dedukcyjny. Hasłowo przypomnę, że pierwszy wzór to: nieuprzedzona obserwacja, indukcyjne wyprowadzanie hipotez, weryfikowanie ich w eksperymencie, drugi zaś: budowanie teorii, dedukcyjne wyprowadzanie z nich hipotez, krytyczne ich sprawdzanie poprzez falsyfikację (Chalmers, 1997). W ramach poszczególnych dyscyplin konkretyzacja tych czynności, w tym ich różnicowanie, dokonuje się na poziomie metod i technik badawczych, ale kryteria ich oceny wynikają z reguł nadrzędnej metody naukowej.

W naukach przyrodniczych jakość badania oceniana jest ze względu na jego efekt, a nie drogę do niego prowadzącą. Ta ostatnia jest o tyle ważna, że jej powtórzenie przez innych powinno prowadzić do tego samego rezultatu, jak uzyskany pierwotnie. W naukach społecznych powtarzalność wyników jest problematyczna - być może dlatego większe znaczenie przypisywane było stosowanej metodzie i jej zgodności z uznawanym wzorcem naukowości. W okresie dominacji normatywnej metodologii w dyscyplinach najsilniej aspirujących do naukowości, takich jak np. psychologia, konsekwentnie podejmowano zabiegi dostosowujące przedmiot ich badań do obowiązującej metody ${ }^{3}$. Nadrzędnym ich celem jest uzyskanie kontroli nad badanymi obiektami poprzez dopuszczenie do ujawniania się tylko ich określonych wymiarów. Dokonuje się to poprzez wybór zmiennych tworzących badany przedmiot, określenie relacji między nimi oraz prowadzenie pomiaru. Istotną kwestią jest

3 W pedagogice takiej konsekwencji nie było (por. Urbaniak-Zając, 2013, s. 19-32). 
także sposób i warunki pozyskania danych empirycznych - im bardziej ograniczają one indywidualność uczestników i realizatorów badań, tym lepiej. Konsekwencją jest rangowanie metod badawczych zależnie od ich bliskości do wzoru („lepszy” jest wywiad standaryzowany niż swobodny).

W tradycyjnym ujęciu metody badawcze w naukach społecznych są nie tylko legitymizowane ich adekwatnością wobec metody naukowej, dzięki czemu nie wymagają teoretycznego uzasadnienia, ale są także ukazywane jako "gotowe do użycia”. Wprawdzie w literaturze metodologicznej zaleca się dostosowanie metody do przedmiotu, który bada (Niżnik, 1979), ale ten postulat w pedagogice jest zwykle wąsko rozumiany. Wyraźnie to widać w starszych opracowaniach podręcznikowych, które są nadal popularne: przedmiotem metody studium indywidualnego przypadku są określone osoby lub pojedyncze stany rzeczy, przedmiotem sondażu jest zjawisko, a monografii - instytucja pedagogiczna (Kamiński, 1974; Pilch, 1995). Takie powiązanie metody z przedmiotem pokazuje, że ten ostatni ujmowany jest materialnie, rzeczowo, a nie teoretycznie. Ten stan pogłębia traktowanie wywiadu, ankiety, obserwacji itp. jako akontekstowych technik, które mają charakter instrukcji - „tym użyteczniejszej, im wierniej stosowanej" (Kamiński, 1974, s. 54); ci autorzy, którzy przywołane sposoby gromadzenia danych empirycznych nazywają metodami, też eksponują ich wymiar techniczny.

Konkludując, przez długie lata metoda badawcza przedstawiana była jako zbiór czynności neutralnych wobec poznawanych przedmiotów. Zniekształcony obraz przedmiotu mógł powstać tylko w wyniku utraty kontroli nad subiektywnością badaczek i badaczy oraz uczestniczek i uczestników badań. W sytuacji, gdy akceptuje się tylko jeden wzór poznania, osoby prowadzące badania empiryczne nie są mentalnie gotowe dostrzec jego ograniczenia. Wykazują raczej tendencję do ich przysłaniania, nieuznawania ich za znaczące. Z jednej strony obawiają się zarzutu nieumiejętnego stosowania metody, z drugiej - chcą znieść dysonans poznawczy, widząc różnicę między tym, jak być powinno, a jak rzeczywiście jest w praktyce badawczej. Normatywna metodologia nie zajmuje się praktyką badawczą w naukach społecznych, lecz pożądanym sposobem jej prowadzenia, który wynika z obowiązującej metody naukowej ${ }^{4}$.

4 W socjologii prowadzono wprawdzie badania nad praktyką stosowania metod badawczych (dokumentuje to np. seria Metody i próby technik badawczych w socjologii). Ich celem była jednak nie tyle krytyczna ocena metod, ile identyfikacja uwarunkowań błędów albo niepożądanych stanów rzeczy (np. brak odpowiedzi na pytania ankietowe), by można je było w kolejnych badaniach usunąć lub poddać kontroli. 


\section{Osłabienie opozycji teoria - empiria Konsekwencje dla metody}

Zniesiony przez pozytywizm związek między badaniami empirycznymi a filozofią nabrał znaczenia w następstwie drugiego przełomu antypozytywistycznego (Mokrzycki, 1984) i najwyraźniej odzwierciedlił się w badaniach jakościowych. Prowadzące je osoby odwołują się do analiz fenomenologicznych, hermeneutycznych, semiotycznych itd., czyniąc poszczególne stanowiska filozoficzne źródłem założeń konstytuujących specyfikę badanych przedmiotów i możliwości ich empirycznego ujmowania. Te ustalenia są punktem wyjścia do tworzenia metody badawczej albo wyboru najbardziej właściwej spośród już stosowanych. Niektóre przywoływane dzisiaj analizy filozoficzne prowadzone były wiele dziesiątków lat temu, ale wówczas - jak już wspominałam w poprzedniej części - nie odnoszono ich w ogóle do badań empirycznych. Przykład z dziedziny pedagogiki: Władysław Zaczyński uznawał w swoim podręczniku hermeneutykę za drogę formułowania twierdzeń pedagogicznych, ale tylko twierdzeń pedagogiki normatywnej (1967, s. 110-112). Pedagogikę tę zaś Heliodor Muszyński jednoznacznie sytuował „w tradycji spekulatywnych dociekań, mających niewiele wspólnego z empirycznymi badaniami jakiejkolwiek rzeczywistości" (1967, s. 62).

We współczesnych opracowaniach powstałych na podstawie badań jakościowych ich autorki i autorzy mniej czy bardziej szczegółowo przedstawiają przyjmowane założenia ontologiczne i epistemologiczne. Można więc przypuszczać, że mają świadomość współzależności sposobu ujmowania przedmiotu, metody jego badania oraz uzyskiwanych wyników. O metodzie nie można więc myśleć bez jej przedmiotowego odniesienia, ale jednocześnie uzyskany w wyniku badań obraz przedmiotu jest od niej uzależniony. Nie jest ona ani neutralna, ani autonomiczna. Sama nie rozstrzyga o statusie gromadzonych za jej pomocą danych (co oddają "fakty” czy „fikcje”?), wynika on z usytuowania tych danych w jakiejś całości (Kalthoff, 2015, s. 17), z konceptualizacji badanej rzeczywistości. Tym samym rozwiązań metodologicznych nie można odseparować od ustaleń teoretycznych, innymi słowy - prezentacja metody badawczej nie może pomijać konceptualizacji przedmiotu badań.

W praktyce pedagogicznych badań jakościowych ujawnia się jednak także stanowisko będące odwrotnością powyższego - stanowisko naiwnego empiryzmu. Opiera się ono na wierze w bezpośrednie, nieuprzedzone, a przez to wolne od zafałszowań, poznanie. W praktyce prowadzenia badań objawia się ono rezygnacją z hipotez, czasami także z problematyki badawczej, oraz wiarą w to, że osoby uczestniczące w badaniach są najlepszymi ekspertami w dziedzinie własnego życia. Dlatego wypowiedzi 
udzielane podczas wywiadów narracyjnych czy swobodnych traktowane są jako „czysty” materiał empiryczny, który jest bezpośrednim odzwierciedleniem przedmiotu badań (moga go zniekształcić niekorzystne warunki prowadzenia wywiadów). W ten sposób ma być odtwarzany rzeczywisty świat ludzi, a nie świat stworzony przez teoretyków. Stefan Hirschauer zauważa, że w tej postawie tkwią reminiscencje filozofii życia, sugerujące możliwość dotarcia do istoty rzeczywistości ludzkiej pod warunkiem odrzucenia wzorów naukowych. Badania jakościowe miałyby budować „rezerwaty naturalności", w których codzienne konstrukcje sensu byłyby chronione przed „teoretycznymi zanieczyszczeniami” (2015, s. 181).

Uogólniając, można powiedzieć, że cechą nowego myślenia nad metodami badawczymi w poznaniu empirycznym jest osłabienie opozycji teoria - empiria. W ujęciu tradycyjnym ta pierwsza jest tworem umysłu ludzkiego (świat konstrukcji teoretycznych), ta druga zaś (świat faktów empirycznych) - tworem natury albo organistycznego społeczeństwa, funkcjonującego według stałych reguł. W tym kontekście metoda jest niezależnym instrumentem pozwalającym sprawdzać zgodność myśli - a dokładnie zdań - z obiektywnie istniejącym, empirycznym stanem rzeczy. Dzisiaj taki porządek podawany jest w filozofii nauki w wątpliwość. Twierdzenie: „To, co rzeczywiste, nie jest rzeczywiste w ogóle, lecz ze względu na sposób podejścia" (Sikora, 2004, s. 14), nie zostało sformułowane w odniesieniu do przedmiotu nauk społecznych, lecz przyrodniczych. Eksponuje ono umowność „faktów” również w tych dziedzinach, w których obiekty wydają się bez wątpienia realne. Z przyjęcia, że obraz empirii jest zależny od zastosowanego wobec poznawanej rzeczywistości instrumentarium badawczego, nie musi jednak wynikać, że nie ma on realnych podstaw ani że konstruowanie rzeczywistości jest dowolne. Oznacza jedynie pogodzenie się z ograniczeniami poznania ludzkiego. Dają one o sobie znać zarówno w laboratoriach naukowych, jak i w środowisku życia ludzi, do którego wkraczają badaczki i badacze.

Podstawowa różnica związana ze specyfiką dziedziny, w której prowadzi się badania, ma naturę bardziej etyczną niż metodyczną. W badaniach przyrodniczych poznawany obiekt poddawany jest różnorodnym praktykom manipulacyjnym, włącznie z jego destrukcją. Manipulowanie ludźmi w badaniach empirycznych jest niedopuszczalne (współcześnie nie można byłoby przeprowadzić wielu znanych eksperymentów psychologicznych), więcej nawet - za niedopuszczalne uznaje się dzisiaj wkraczanie w prywatność ludzi bez ich świadomej zgody (Lofland, Snow, Anderson, Lofland, 2009, s. 61-88). Te warunki wydają się oczywiste, gdy ujmuje się je bezkontekstowo, kiedy jednak przenoszone są na praktykę badawczą, zyskują dylematyczny wymiar (każdej decyzji towarzyszą wątpliwości). Dla przykładu: wcale nie jest klarowne, co to znaczy świadoma zgoda - wyrażając zgodę na udział w badaniach przed ich rozpoczęciem, 
uczestniczka lub uczestnik nie wiedzą, jak będą wykorzystywane ich wypowiedzi (sama badaczka lub badacz tego nie wie), nie wiedzą więc w pełni, na co się zgadzają. Nie możemy również zapomnieć, że dokładna informacja o przedmiocie i celu badań ma znaczenie dla zachowania - werbalnego i niewerbalnego - ludzi. Zbieranie materiału badawczego bez zgody osób tym badaniom poddawanych nie było w przeszłości kwestionowane, ponieważ w klasycznej metodzie badawczej priorytetem jest eliminowanie czynników zaburzających obiektywność. Dzisiaj, kiedy możliwość obiektywnego poznania jest kwestionowana, badaczki i badacze muszą odwoływać się do innych wartości/celów jako uwarunkowań swoich decyzji. Dla zwolenników badań określanych jako krytyczne, partycypacyjne, interwencyjne instrumentalne wykorzystywanie ludzi jako źródła informacji w nieznanych im celach nie ma żadnego uzasadnienia. Prowadzenie badań ingerujących w świat życia ludzi legitymizuje wyłącznie wywołanie zmiany społecznej, która jest korzystna dla uczestników badań (Červinková, Gołębniak, 2010). W tej perspektywie aktywność badawcza nie jest uzasadniana dążeniem do wiedzy prawdziwej, lecz użytecznej, służącej demokratyzacji, wzrostowi sprawiedliwości i podobnych wartości. Ta konstatacja, odniesiona do metody, zwraca uwagę, że adekwatność tej ostatniej wobec celu badań jest równie ważna, jak adekwatność wobec ujętego myślowo przedmiotu.

\section{Zakończenie}

Uniwersalność i neutralność metody naukowej i adekwatnych wobec niej metod badawczych były konsekwencją zabiegów filozofów, którzy realnej nauce przypisali własne wyobrażenie doskonałego poznania, co paradoksalnie oderwało metodę naukową od uzasadniającego ją kontekstu filozoficznego. W pozytywistycznej perspektywie niezależnie od dziedziny doświadczenia przyjęto, że „sposoby zdobywania wiedzy są zasadniczo takie same" (Kołakowski, 2010, s. 16). Jakość aplikacji metody przez daną dyscyplinę była - i przez zwolenników tradycji nadal jest - traktowana jako wskaźnik jej naukowości (jedne nauki uznaje się za bardziej dojrzałe, inne mniej). W tym ujęciu metoda jest nie tylko autonomiczna, ale i neutralna, tzn. przyjmuje się, że jeśli jest właściwie stosowana, to oddaje świat takim, jakim on jest. Prowadzenie krytyki metodologicznej w takich warunkach jest relatywnie proste. Polega na odnoszeniu konkretnych projektów badawczych do uznanego zespołu reguł i procedur.

Pozycja metody ulega istotnej zmianie, kiedy podważone zostają jej autonomiczność i neutralność. Dokonuje się to w wyniku odsłaniania złożoności relacji podmiot - przedmiot poznawania. Różne stanowiska 
filozoficzne stają się przesłankami różnych metod badawczych. W warunkach dopuszczalności wielości tych ostatnich zmienia się ich status: nie tyle oddają one w realistyczny sposób rzeczywistość, ile pokazują, jak można ją ujmować, do jakiego jej aspektu uzyskuje się dostęp (Kalthoff, 2015, s. 17). W ocenie metody podkreśla się przede wszystkim jej adekwatność wobec przedmiotu badań, ale jednocześnie wiadomo, że jest on prekonceptualizowany, a konstytuujące go założenia określają warunki jego empirycznej dostępności. Metoda staje się więc częścią zagadnienia, które jest za jej pomocą poznawane. Stefan Hirschauer (2015, s. 180) formułuje tę myśl radykalnie: być adekwatnym do przedmiotu to do niego należeć. Wydaje się, że w tych warunkach metodologię nauk społecznych w mniejszym stopniu definiuje się przez metodę, a w większym przez sposób ujmowania przedmiotu badań, a także ich nadrzędny cel (por. badania krytyczne, partycypacyjne).

Tak mocna filozoficzno-teoretyczna podbudowa metod badawczych ma konsekwencje dla praktyki badań empirycznych. Chcę zwrócić uwagę tylko na dwie, ponieważ w moim mniemaniu mają one znaczenie dla ujmowania współczesnej krytyki metodologicznej. Po pierwsze, aktualny stan rzeczy sprzyja separowaniu się zwolenniczek i zwolenników jednej metody od zwolenniczek i zwolenników innych metod. Po drugie, kiedy czyta się teksty relacjonujące konkretne badania empiryczne i ich wyniki, nierzadko rodzi się wrażenie, że o ich wartości mają rozstrzygać przyjmowane założenia filozoficzno-teoretyczne. Często nie wiadomo, w jaki sposób te ostatnie przenoszone są na metodyczne postępowanie badaczek i badaczy prowadzące do uzyskanych wyników. Czytelnik musi więc uwierzyć w ich wiarygodność, bo nie ma żadnych informacji pozwalających śledzić proces ich powstawania. Nie zrównuję metodyczności postępowania z wiarygodnością poznania, ale uznaję metodyczność za specyficzną cechę poznania naukowego.

Metoda badawcza jako zespół zasad wynikających z założeń ontologiczno-epistemologicznych, mających metodyczne implikacje, jest formą dyscyplinarnej komunikacji. Ujmuje aspekt poznawanej rzeczywistości i specyfikę tego poznawania, a także możliwości uogólniania uzyskiwanych wyników. Określa tym samym możliwości teoretyzowania, co jest o tyle ważne, że sposobem dowartościowania badań jakościowych ma być tworzenie z ich pomocą nowych teorii przedmiotowych. Jest ona także formą autodyscyplinowania badaczek i badaczy. Niezależnie od tego, czy opracowują oni własną metodę, czy wybierają jakąś spośród już istniejących, powinni mieć świadomość potrzeby dystansu wobec tego, co robią w procesie badawczym. Ten dystans wyraża się w umiejętności relacjonowania swoich działań, wskazywania zamierzonego celu i porównywania go z osiąganymi rezultatami. 
W warunkach, w których każda norma metodologiczna i każda reguła mogą być zakwestionowane, krytyka metodologiczna może służyć jedynie refleksji nad praktyką badawczą (a nie jej jednoznacznej ocenie). To praktyka jest źródłem efektywnej wiedzy o metodach, to na jej gruncie okazuje się, co jest, a co nie jest możliwe i jakie są sytuacyjne konsekwencje decyzji podejmowanych przez badaczki i badaczy. Prowadzenie takiej krytyki wymaga jednak od autorek i autorów publikacji pełniejszych informacji o planowaniu i przebiegu badań empirycznych. Krytyka metodologiczna rekonstruująca konteksty założeń (ontologicznych, epistemologicznych, aksjologicznych) przyjmowanych w różnych metodach, rekonstruująca związki między nimi i ich różnorakie konsekwencje, może służyć osłabianiu separatyzmów metodologicznych. Warto poszukiwać szerszych horyzontów pozwalających na co najmniej wariantową integrację różnych podejść (np. Piekarski, 2017). Innymi słowy, współczesne analizy metodologiczne wymagają stosowania reguł hermeneutyki. Otwartości na różne punkty widzenia, bo niezależnie od siły ugruntowania jednego zbioru przekonań inny, w zmienionym kontekście, może być równie słuszny (Grondin, 2015). Istotne jest nieutożsamianie porządku terminologicznego - powiązanego z mniej czy bardziej sztywną systematyką stanowisk filozoficznych - z plastycznym porządkiem praktyki badawczej, ukierunkowanej na osiąganie właściwych jej celów. Jeśli akceptuję twierdzenie, że bezpośredni dostęp do rzeczywistości nie jest możliwy, to nie znaczy, że muszę być konstruktywistką odcinającą się od realizmu; jeśli przyjmuję, że poznanie naukowe różni się od potocznego, a więc powinno być metodyczne i dążyć do uogólnień, to nie znaczy, że jestem pozytywistką; prowadząc badania empiryczne, nie muszę ograniczać tego, co da się pomyśleć, do tego, co zostało wprost powiedziane przez uczestniczki i uczestników badań. Osłabianie opozycji nie ma służyć rezygnacji z reguł, lecz rozumieniu warunków ich stosowania.

\section{Bibliografia}

Amsterdamski, S. (1983). Między historią a metodą. Warszawa: PIW.

Červinková, H., Gołębniak, B.D. (2010). Badania w działaniu. Pedagogika i antropologia zaangażowane. Wrocław: WN DSW.

Chalmers, A. (1997). Czym jest to, co zwiemy nauką? Wrocław: Siedmioróg.

Dilthey, W. (1987). Przeżywanie i rozumienie (s. 204-213). W: Z. Kuderowicz, Dilthey. Warszawa: Wiedza Powszechna.

Grobler A. (2006). Metodologia nauk. Kraków: Aureus, Znak.

Grondin, J. (2015). Gadamera doświadczenie i teoria wychowania: uczenie się, że inny może mieć rację. Kwartalnik Pedagogiczny, 2(236), 11-29.

Hirschauer, S. (2015). Die Empiriegeladenheit von Theorien und der Erfindungsreichtum der Praxis (s. 165-187). W: H. Kalthoff, S. Hirschauer, G. Lindemann (Hg.), Theoretische Empirie. Zur Relevanz qualitativer Forschung. Frankfurt a. M.: Suhrkamp. 
Kalthoff, H. (2015). Einleitung: Zur Dialektik von qualitativer Forschung und soziologischer Theoriebildung (s. 8-32). W: H. Kalthoff, S. Hirschauer, G. Lindemann (Hg.), Theoretische Empirie. Zur Relevanz qualitativer Forschung. Frankfurt a. M.: Suhrkamp.

Kamiński, A. (1974). Metoda, technika, procedura badawcza w pedagogice empirycznej (s. 49-79). W: R. Wroczyński, T. Pilch (red.), Metodologia pedagogiki społecznej. Wroclaw: Ossolineum.

Kamiński, S. (1992). Nauka i metoda. Pojęcie nauki i klasyfikacja nauk. Lublin: Towarzystwo Naukowe KUL.

Kołakowski, L. (2003). Filozofia pozytywistyczna. Warszawa: Wydawnictwo Naukowe PWN.

Lehrberger, C. (2009). Die „realistische Wendung” im Werk von Heinrich Roth. München: Waxmann.

Lofland, J., Snow, D.A., Anderson, L., Lofland, L.H. (2009). Analiza układów społecznych. Przewodnik metodologiczny po badaniach jakościowych. Warszawa: Scholar.

Malewski, M. (2017). Badania jakościowe w metodologicznej pułapce scjentyzmu. Teraźniejszość - Człowiek - Edukacja, 2(78), 129-136.

Mokrzycki, E. (1984). Kryzys i schizma: antyscjentystyczne tendencje w socjologii. Warszawa: PIW.

Muszyński, H. (red.) (1967). Metodologiczne problemy pedagogiki. Wrocław: Ossolineum.

Niżnik, J. (1979). Przedmiot poznania w naukach społecznych. Warszawa: PWN.

Nowak, S. (1985). Metodologia badań społecznych. Warszawa: PWN.

Pasikowski, S. (2016). Kwestionariusz gotowości przeciwstawiania się. Podręcznik Pracowni Narzędzi Badawczych KNP PAN. Przegląd Badań Edukacyjnych, 23a.

Piekarski, J. (2017). Perspektywa uczestnicząca w badaniach empirycznych - zarys tematyczny. Przegląd Badań Edukacyjnych, 2(25), 267-298.

Pilch, T. (1995). Zasady badań pedagogicznych. Warszawa: Żak.

Siemek, M. (1989). „Nauka” i "naukowość” jako ideologiczne kategorie filozofii (s. 13-29). W: H. Kozakiewicz, E. Mokrzycki, M.J. Siemek (red.), Racjonalność, nauka, społeczeństwo. Warszawa: PWN.

Sikora, M. (2004). O dyskursie nauki jako badaniu, twórczości i działaniu (s. 9-25). W: P. Madejski (red.), Wielość form dyskursów poznawczych. Wrocław: Politechnika Wrocławska.

Ulanowski, T. (2008). Inne życie. Rozmowa z A. Wolszczanem. Wysokie Obcasy, 3.

Urbaniak-Zając, D. (2013). Pozycja badań jakościowych w tradycyjnym modelu empirycznych badań pedagogicznych (s. 19-32). W: D. Urbaniak-Zając, E. Kos, Badania jakościowe w pedagogice. Warszawa: Wydawnictwo Naukowe PWN.

Urbaniak-Zając, D. (2017). Proces badawczy jako podejmowanie decyzji - refleksja metodologiczna (s. 181-195). W: D. Kubinowski, M. Chutorański (red.), Pedagogika jako humanistyczno-społeczna nauka stosowana: konsekwencje metodologiczne. Kraków: Oficyna Wydawnicza „Impuls".

Zaczyński, W. (1967). Rozwój metody eksperymentalnej i jej zastosowanie. Warszawa: PWN.

\section{From the universality to the particularity of the research method}

\section{SUMMARY}

The aim of the chapter is to discuss the conditions for changing the status of the research method and consequences of the change. In the traditional approach, the research method is a refinement of the scientific method, which is an emanation of the ideal of modern science. So, the rules that govern the research method follow the science ideal. As long as one pattern of science existed, the method of natural sciences was considered commonly obligatory and did not require separate justifications. In the chapter, the author signals the genesis of the special position of the method in modern science and draws attention to the 
consequences of W. Dilthey's exclusion of humanistic sciences (including contemporary social sciences) from empirical knowledge, then focuses on conditions that impaired the autonomy of the research method. She discusses the consequences of this change for the practice of qualitative empirical research. In conclusion, the author refers to the links between the research method, the research subject and the assumptions referring to it; and signals the change of function and position of the method (it does not reflect reality in a realistic way, but shows how it can be understood; and thus it becomes a part of the problem being studied by means of the method). The task of methodological critique is reflection on research practice, reconstruction of contexts and assumptions adopted as parts of various research projects, which may serve to weaken the "methodological separatisms".

Keywords: scientific method, research method, normative methodology, ethics in research 